\title{
Fatty acid and cholesterol composition of camel's (Camelus bactrianus, Camelus dromedarius and hybrids) milk in Kazakhstan
}

\author{
Gaukhar KONUSPAYEVA ${ }^{1}$, Émilie LEMARIE ${ }^{2}$, Bernard FAYE ${ }^{3 *}$, \\ Gérard LOISEAU ${ }^{2}$, Didier MONTET ${ }^{2}$
}

\author{
${ }^{1}$ Al Farabi Kazakh National University, 71 av. Al Farabi, 050073, Almaty, Kazakhstan \\ ${ }^{2}$ UMR Qualisud, CIRAD, TA B-95/16, 73 rue J.-F. Breton, 34398 Montpellier Cedex 5, France \\ ${ }^{3}$ CIRAD - Département Environnements et Sociétés, Campus International de Baillarguet, \\ TA C-DIR / B, 34398 Montpellier Cedex 5, France
}

Received 27 June 2007 - Accepted 11 October 2007

\begin{abstract}
The fatty acid composition and cholesterol content of 22 camel's milk samples from different regions of Kazakhstan were determined, in different seasons and with different camel species (Bactrian, dromedary and hybrids). Camel milk fat differed from mammalian fats by its high content of the long-chain fatty acids C14:0, C16:0, C18:0 and C18:1. Great differences in fatty acid composition occurred between regions. Short-chain fatty acids (C8:0 and C10:0) were in higher proportion in spring and long-chain fatty acids (C17:0 and C17:1) in autumn. Dromedary milk had a higher proportion of $\mathrm{C} 17: 0$ iso and C18:1 than Bactrian milk. The ratio of unsaturated/saturated acid was more favorable in camel's milk compared with that of cows or other mammalians. All of these parameters gave a nutritional advantage to camel's milk, although it had a higher content of cholesterol (37.1 mg.100 g $\left.{ }^{-1}\right)$ than cow's milk. Multivariate analysis allowed the identification of four types of fatty acid profiles with a clear opposition between the samples rich in short-chain fatty acids and the samples rich in long-chain fatty acids. These results confirmed that environmental and farming conditions allowed modulation of the lipid composition of camel's milk.
\end{abstract}

camel's milk / lipid / fatty acid / cholesterol / Kazakhstan

摘要 - 哈萨克斯坦骆驼 (Camelus bactrianus, Camelus dromedarius and hybrids)奶中脂肪酸 组成和胆固醇含量。分析了来源于哈萨克斯坦不同地区, 不同季节和不同品种 (双峰骆驼、 单峰骆驼和杂交种) 的 22 个骆驼奶样品中脂肪酸和胆固醇含量。骆驼乳脂肪不同于其他的 哺乳动物的乳脂肪, 其长链脂肪酸 (C14:0、C16:0、C18:0 和 $\mathrm{C} 18: 1)$ 含量较高。地区之间乳 脂脂肪酸组成的差异显著。春季骆驼奶中短链脂肪酸 (C8:0、C10:0) 的比例较高, 而秋季骆 驼奶中长链脂肪酸 (C17:0、C17:1) 的比例较高。单峰骆驼奶中 iso-C17:0 和 C18:1 明显高于 双峰骆驼。与牛奶和其他哺乳动物奶相比, 骆驼奶中不饱和/饱和脂肪酸的比例非常合适。 尽管骆驼奶中胆固醇 $\left(37.1 \mathrm{mg} \cdot 100 \mathrm{~g}^{-1}\right)$ 的含量高于牛奶, 但很多数据表明骆驼奶的营养性非 常高。经过多元分析显示在富含短链脂肪酸和富含长链脂肪酸骆驼奶样品之间四类脂肪酸 的性质完全相反。试验结果证明了环境和放牧条件对骆驼奶脂质组成有一定的影响。

骆驼奶 / 脂质 / 脂肪酸 / 胆固醇 / 哈萨克斯坦

* Corresponding author (通讯作者): faye@cirad.fr 
Résumé - Composition des lipides du lait de chamelle (Camelus bactrianus, Camelus dromedarius et hybrides) au Kazakhstan. La composition en acides gras et la teneur en cholestérol ont été déterminées dans 22 échantillons de lait de chamelle du Kazakhstan, provenant de différentes régions, à différentes saisons et de différentes espèces (chameau de Bactriane, dromadaire et hybrides). La matière grasse du lait de chamelle comprend comme acides majeurs C14:0, C16:0, C18:0 et C18:1. Les acides gras à chaînes courtes $(C 8: 0, C 10: 0)$ sont en proportion plus élevée au printemps et ceux à chaînes longues $(\mathrm{C} 17: 0, \mathrm{C} 17: 1)$ en automne. Le lait de dromadaire a surtout une plus forte proportion en C17:0iso et C18:1 que le lait de Bactriane. Le rapport acides insaturés/acides saturés est en faveur du lait de chamelle comparé au lait de vache. Cette composition donne un avantage nutritionnel au lait de chamelle, mais sa teneur en cholestérol $\left(37,1 \mathrm{mg} \cdot 100 \mathrm{~g}^{-1}\right)$ est plus élevée que dans le lait de vache. L'analyse multivariée a permis d'identifier quatre types de profils d'acides gras avec une claire opposition entre des laits riches en acides à courtes chaînes et des laits riches en acides à longues chaînes. Ces résultats confirment que l'environnement et les conditions d'élevage permettent de moduler la composition des lipides du lait de chamelle.

lait de chamelle / lipides / acides gras / cholestérol / Kazakhstan

\section{INTRODUCTION}

In Kazakhstan, the genus Camelus includes two species cohabiting in the same areas and even on the same farms: the onehumped camel (Camelus dromedarius) and the Bactrian two-humped camel (Camelus bactrianus), and their hybrids [16]. This particular fact allows the comparison of milk composition of those animals reared in similar environment. Elsewhere, raw camel's milk and a fermented product (named shubat) have always been an important food for Kazakh peoples. Shubat is especially renowned and is used for some medicinal purposes $[9,18]$. Milk fatty acid composition is one of the aspects linked to the discussion on the health effects of camel's milk and milk products [27]. However, the fatty acid composition of camel's milk is not well documented [10], especially in Bactrian camels [28]. This study carried out a precise analysis of lipids by gas chromatography/mass spectrometry and cholesterol contents for 22 milk samples from 4 different sites.

\section{MATERIALS AND METHODS}

\subsection{Sampling procedure}

Twenty-two camel's milk samples were used for the present study. They originated from four regions of Kazakhstan (Almaty, Atyrau, Aralsk and Shymkent) and the milk was collected in four different seasons. The samples came from 7 Bactrian camels, 10 dromedaries, 3 hybrids and 2 from mixed milk. This sampling procedure aimed to maximize the observed variability. The samples were collected after milking, stored at $4{ }^{\circ} \mathrm{C}$ until they reached the laboratory, then frozen and stored at $-18{ }^{\circ} \mathrm{C}$ until their analysis.

\subsection{Laboratory analysis}

\subsubsection{Total milk lipid extraction}

The extraction of total lipids in the camel's milk was based on the RoseGottlieb method [8] with modification by IDF 172:1995. As the method has never formerly been described for camel's milk, samples of cow's milk UHT Lactel ${ }^{\circledR}$ at $3.4 \%$ fats and half-skimmed UHT Lactel ${ }^{\circledR}$ at $1.5 \%$ fats were used as references to test the analysis protocol.

Milk samples were heated up to $40{ }^{\circ} \mathrm{C}$ in tubes then put for $10 \mathrm{~min}$ in an ultrasonic bath. Ten $\mathrm{mL}$ of the sample were mixed in a flask by magnetic agitation with $2 \mathrm{~mL}$ ammonia and $10 \mathrm{~mL}$ ethanol for $10 \mathrm{~min}$, then this solution was mixed in a separating funnel with $1 \mathrm{~mL}$ of $30 \%$ ammonia 
and $10 \mathrm{~mL} 95 \%$ (v/v) ethanol. Then $20 \mathrm{~mL}$ ethylic ether were added and mixed for $1 \mathrm{~min}$. Twenty $\mathrm{mL}$ hexane were added and shaken. After separating into two phases, the water phase was retained and the organic phase was decanted into another separating funnel. The extraction was repeated twice with $20 \mathrm{~mL}$ hexane on the water phase. The organic phase was filtrated on hydrophobic cotton soaked in hexane and covered with anhydrous sodium sulfate.

The filtrate was transferred to a roundbottomed flask which had been dried for $30 \mathrm{~min}$ in an oven at $100{ }^{\circ} \mathrm{C}$ then kept for $30 \mathrm{~min}$ in a dessiccator. Hexane was removed in a rotary vacuum evaporator at $50{ }^{\circ} \mathrm{C}$, and then the flask was kept for $30 \mathrm{~min}$ at $100{ }^{\circ} \mathrm{C}$, and for $45 \mathrm{~min}$ in a dessiccator before weighing.

The extracted lipids were stored in hexane at $4{ }^{\circ} \mathrm{C}$ until analysis.

\subsubsection{Fatty acid analyses}

Fatty acids were determined after methylation by gas chromatography and were confirmed by mass spectrometry for each milk sample.

A Varian 3400 gas chromatograph (Ajax, Canada) was equipped with a nonpolar DB-Wax capillary column (molten silica) of $60 \mathrm{~m}$ length, $0.32 \mathrm{~mm}$ diameter and $0.25 \mu \mathrm{m}$ film thickness. All other conditions were those described by Collomb and Bühler [7]. An Agilent 6890 Series GC System (Massy, France) was used for mass spectrometry with soft gcms 59 . Some saturated fatty acids are well known for their risk regarding coronary heart disease. The risk due to fatty acid composition can be evaluated with the index of atherogenicity. The index of atherogenicity (IA) was calculated as reported by Ulbricht and Southgate [27], namely:

$$
\mathrm{IA}=\frac{\mathrm{aS}_{\underline{12}}+\mathrm{bS}_{\underline{14}}+\mathrm{cS}_{\underline{16}}}{\mathrm{dP}+\mathrm{eM}+\mathrm{fM}^{\prime}}
$$

where: $S_{\underline{12}}=C 12: 0, S_{14}=C 14: 0$ and $S_{16}$ $=\mathrm{C} 16: 0 ; \overline{\mathrm{P}}=$ sum of $\omega \overline{6}$ and $\omega 3$ PUFA; $\overline{\mathrm{M}}$ $=$ oleic acid and $\mathrm{M}^{\prime}=$ sum of other MUFA. $\mathrm{a}-\mathrm{f}$ are empirical constants: $\mathrm{b}=4$ and $\mathrm{a}, \mathrm{c}$, $\mathrm{d}$, e and $\mathrm{f}$ are equal to 1 .

Iso fatty acids were not included in the calculation.

So, the final calculation of the IA was: $\left(\mathrm{C} 12: 0+\left(4^{*} \mathrm{C} 14: 0\right)+\mathrm{C} 16: 0\right) /(\mathrm{C} 10: 1+$ $\mathrm{C} 14: 1+\mathrm{C} 16: 1+\mathrm{C} 17: 1+\mathrm{C} 18: 1+\mathrm{C} 18: 2$ + C18:3).

\subsubsection{Cholesterol analysis}

The determination of cholesterol was achieved by using the enzymatic kit of R-Biopharm (Saint-Didier au Mont d'Or, France) (Ref.: 10139050 035) on 10 milk samples.

\subsubsection{Statistical analysis}

As the objective is to have an idea of the variability of fatty acid composition with at least one sample in each cell region/species/season, ANOVA was not applicable to test the interactions. Only the variations due to each factor separately were tested (species, region or season). Fatty acid profiles were achieved with multivariate analysis using Winstat(C) software (CIRAD, Montpellier, France). In order to take into account each fatty acid with the same weight, the values were divided into 3 modalities with a balanced number of samples in each modality: 1 for the lower values (modality 1), 2 for the mean values (modality $\mathrm{m}$ ) and 3 for the higher values (modality h). Finally, the obtained qualitative data table was analyzed with multiple correspondence factorial analysis (MCFA) followed by a cluster analysis to identify the types of samples according to their fatty acid composition. 
Table I. Fatty acid composition of camel milk fat in Kazakhstan.

\begin{tabular}{cccclc}
\hline$\#$ & Acids & Mean and SD & $\#$ & Acids & Mean and SD \\
\hline 1 & C4:0 & $0.37 \pm 0.41$ & 14 & C16:0iso & $0.28 \pm 0.18$ \\
2 & C6:0 & $0.38 \pm 0.28$ & 15 & C16:0 & $31.34 \pm 4.19$ \\
3 & C8:0 & $0.40 \pm 0.32$ & 16 & C16:1 & $6.93 \pm 1.54$ \\
4 & C10:0 & $0.35 \pm 0.40$ & 17 & C16:0dm & $0.40 \pm 0.24$ \\
5 & C10:1 & $0.85 \pm 1.15$ & 18 & C17:0iso & $0.63 \pm 0.30$ \\
6 & C12:0 & $1.01 \pm 0.46$ & 19 & $\mathbf{C 1 7 : 0}$ & $0.68 \pm 0.22$ \\
7 & C13:0 & $0.07 \pm 0.21$ & 20 & $\mathbf{C 1 7 : 1}$ & $0.35 \pm 0.17$ \\
8 & C14:0iso & $0.16 \pm 0.14$ & 21 & $\mathbf{C 1 8 : 0}$ & $16.33 \pm 4.61$ \\
9 & C14:0 & $12.83 \pm 4.11$ & 22 & $\mathbf{C 1 8 : 1}$ & $21.40 \pm 5.40$ \\
10 & C14:1 & $0.73 \pm 0.35$ & 23 & $\mathbf{C 1 8 : 2}$ & $1.37 \pm 0.48$ \\
11 & C14:0dm & $0.38 \pm 0.27$ & 24 & $\mathbf{C 1 8 : 3}$ & $0.60 \pm 0.56$ \\
12 & C15:0iso & $0.79 \pm 0.20$ & 25 & $\mathbf{C 2 0 : 0}$ & $0.02 \pm 0.07$ \\
13 & C15:0 & $1.30 \pm 0.34$ & 26 & $\mathbf{C 2 0 : 1}$ & $0.01 \pm 0.04$ \\
\hline
\end{tabular}

Note: $\mathrm{dm}=13$-dimethyltetradecanoic.

\section{RESULTS}

\subsection{Lipid composition}

The average lipid concentration in our samples was $6.40( \pm 2.69) \%$, with a wide range from 3.52 to $14.06 \%$. The composition of the main fatty acids (expressed in \% mass) in camel's milk was C14:0, 12.8\%; C16:0, 31.3\%; C18:0, 16.3\%; and $\mathrm{C} 18: 1,21.4 \%$ (Tab. I). On average, the short-chain fatty acids (SCFA) were $1.16( \pm 0.93) \%$. The proportion was 18.49 $( \pm 5.60) \%$ for medium chains (MCFA) and $80.36( \pm 6.33) \%$ for long chains (LCFA).

Fatty acid (FA) composition showed that many of them varied highly significantly $(P \leq 0.01)$, by regions especially: C6:0, C14:0dm, C16:1, C17:0, C18:0 and C18:3 (Tab. II). Other fatty acids varied significantly at $P<0.05$ (C12:0, C14:1, C16:0, C16:0iso, C16:0dm, C17:1 and C18:1). The caproic acid (C6:0) percentage in the Almaty region $(0.21 \%)$ was threefold less than in the Shymkent region $(0.59 \%)$; 13-dimethyltetradecanoic acid (C14:0dm) was 5 times higher in Almaty $(0.65 \%)$ than in Shymkent $(0.14 \%)$, and palmitoleic (C16:1) acid was higher in the Shymkent region $(7.70 \%)$ and lower in the Aralsk region (5.50\%). Linolenic acid (C18:3) was 4 times lower in the Almaty region $(0.18 \%)$ than in the Shymkent and Aralsk regions $(0.95 \%)$. On average, the milk samples from the Aralsk region were significantly poorer in short-chain fatty acids (Tab. II).

The fatty acid composition varied by season, and the main variation involved especially $(P<0.01) \mathrm{C} 8: 0, \mathrm{C} 10: 0, \mathrm{C} 10: 1$, C17:0, C17:1 and C20:0 (Tab. III). At $P<0.05, \mathrm{C} 4: 0$ and $\mathrm{C} 12: 0$ were significantly higher in the spring season (Tab. III). Caprylic (C8:0), capric (C10:0) and 2-decylenoic acids were present in higher concentration in the spring season. Palmitic acid (C16) was lower in winter. Arachidic acid (C20:0) content was higher in winter than in all other seasons (Tab. III). The seasonal effect was not significant on the global composition.

Fatty acid composition by species showed that C14:0, C17:0iso and C18:1 varied significantly at $P<0.01$ (Tab. IV). Four other FA varied significantly at $P<$ 0.05 (C8:0, C12:0, C14:1 and C20:1). The myristic acid (C14:0) concentration 
Table II. Fatty acid composition of camel milk fat from 4 regions of Kazakhstan (IA: index of atherogenicity; SCFA: short-chain fatty acids; MCFA: medium-chain fatty acids; LCFA: long-chain fatty acids).

\begin{tabular}{|c|c|c|c|c|c|}
\hline Acids & Almaty $(n=6)$ & Atyrau (n=6) & Aralsk $(\mathrm{n}=2)$ & Shymkent $(\mathrm{n}=8)$ & $P$ value \\
\hline C4:0 & $0.37 \pm 0.37$ & $0.36 \pm 0.14$ & $0.09 \pm 0.01$ & $0.46 \pm 0.60$ & $\mathrm{~ns}$ \\
\hline C6:0 & $0.21 \pm 0.16^{\mathrm{a}}$ & $0.34 \pm 0.16^{\mathrm{a}}$ & $0.15 \pm 0.01^{\mathrm{b}}$ & $0.59 \pm 0.34^{\mathrm{a}}$ & 0.01 \\
\hline C8:0 & $0.23 \pm 0.23$ & $0.36 \pm 0.21$ & $0.17 \pm 0.01$ & $0.62 \pm 0.37$ & ns \\
\hline C10:0 & $0.33 \pm 0.52$ & $0.23 \pm 0.13$ & $0.11 \pm 0.02$ & $0.50 \pm 0.47$ & ns \\
\hline C10:1 & $1.01 \pm 1.60$ & $0.65 \pm 0.27$ & $0.27 \pm 0.02$ & $1.03 \pm 1.38$ & ns \\
\hline C12:0 & $0.76 \pm 0.22^{\mathrm{a}}$ & $1.02 \pm 0.18^{\mathrm{a}}$ & $0.60 \pm 0.08^{\mathrm{b}}$ & $1.31 \pm 0.62^{\mathrm{a}}$ & 0.02 \\
\hline C13:0 & $0.05 \pm 0.07$ & $0.03 \pm 0.04$ & $0.01 \pm 0.01$ & $0.14 \pm 0.36$ & $\mathrm{~ns}$ \\
\hline C14:0iso & $0.24 \pm 0.12$ & $0.15 \pm 0.11$ & $0.10 \pm 0.07$ & $0.13 \pm 0.18$ & $\mathrm{~ns}$ \\
\hline C14:0 & $11.05 \pm 3.53$ & $12.19 \pm 2.93$ & $10.60 \pm 0.85$ & $15.20 \pm 4.98$ & ns \\
\hline C14:1 & $0.70 \pm 0.38^{\mathrm{a}}$ & $0.57 \pm 0.10^{\mathrm{a}}$ & $0.41 \pm 0.10^{\mathrm{b}}$ & $0.96 \pm 0.38^{\mathrm{a}}$ & 0.03 \\
\hline C14:0dm & $0.65 \pm 0.31^{\mathrm{a}}$ & $0.41 \pm 0.08^{\mathrm{a}}$ & $0.49 \pm 0.04^{\mathrm{a}}$ & $0.14 \pm 0.08^{b}$ & $<0.001$ \\
\hline C15:0iso & $0.84 \pm 0.27$ & $0.90 \pm 0.08$ & $0.71 \pm 0.05$ & $0.70 \pm 0.21$ & ns \\
\hline C15:0 & $1.31 \pm 0.21$ & $1.50 \pm 0.42$ & $1.20 \pm 0.00$ & $1.16 \pm 0.35$ & ns \\
\hline C16:0iso & $0.44 \pm 0.22^{b}$ & $0.28 \pm 0.10^{\mathrm{a}}$ & $0.26 \pm 0.02^{\mathrm{a}}$ & $0.16 \pm 0.11^{\mathrm{a}}$ & 0.03 \\
\hline C16:0 & $30.61 \pm 5.11^{\mathrm{a}}$ & $27.93 \pm 3.05^{\mathrm{b}}$ & $31.78 \pm 1.34^{\mathrm{a}}$ & $34.35 \pm 2.50^{\mathrm{a}}$ & 0.02 \\
\hline C16:1 & $7.65 \pm 2.11^{\mathrm{a}}$ & $5.67 \pm 0.66^{\mathrm{b}}$ & $5.50 \pm 0.26^{\mathrm{b}}$ & $7.70 \pm 0.73^{\mathrm{a}}$ & $<0.001$ \\
\hline C16:0dm & $0.54 \pm 0.32^{\mathrm{a}}$ & $0.45 \pm 0.16^{\mathrm{a}}$ & $0.56 \pm 0.04^{\mathrm{a}}$ & $0.22 \pm 0.12^{\mathrm{b}}$ & 0.02 \\
\hline C17:0iso & $0.91 \pm 0.22$ & $0.64 \pm 0.29$ & $0.61 \pm 0.08$ & $0.43 \pm 0.25$ & $\mathrm{~ns}$ \\
\hline C17:0 & $0.70 \pm 0.15^{\mathrm{a}}$ & $0.83 \pm 0.19^{\mathrm{a}}$ & $0.78 \pm 0.08^{\mathrm{a}}$ & $0.54 \pm 0.24^{b}$ & 0.01 \\
\hline C17:1 & $0.45 \pm 0.09^{\mathrm{a}}$ & $0.37 \pm 0.21^{\mathrm{a}}$ & $0.42 \pm 0.04^{\mathrm{a}}$ & $0.25 \pm 0.16^{\mathrm{b}}$ & 0.03 \\
\hline C18:0 & $15.13 \pm 4.95^{\mathrm{a}}$ & $18.76 \pm 3.25^{\mathrm{b}}$ & $22.30 \pm 0.77^{\mathrm{b}}$ & $13.91 \pm 3.94^{\mathrm{a}}$ & 0.003 \\
\hline C18:1 & $23.91 \pm 5.91^{\mathrm{a}}$ & $24.57 \pm 4.55^{b}$ & $20.34 \pm 1.28^{\mathrm{a}}$ & $17.42 \pm 3.87^{\mathrm{a}}$ & 0.03 \\
\hline C18:2 & $1.65 \pm 0.67$ & $1.38 \pm 0.27$ & $1.58 \pm 0.08$ & $1.11 \pm 0.42$ & ns \\
\hline C18:3 & $0.18 \pm 0.13^{b}$ & $0.41 \pm 0.25^{\mathrm{a}}$ & $0.96 \pm 0.24^{\mathrm{a}}$ & $0.96 \pm 0.71^{\mathrm{a}}$ & 0.01 \\
\hline C20:0 & $0.08 \pm 0.12$ & $0.01 \pm 0.02$ & 0.00 & 0.00 & $\mathrm{~ns}$ \\
\hline C20:1 & $0.02 \pm 0.04$ & 0.00 & 0.00 & $0.02 \pm 0.05$ & ns \\
\hline IA & $2.52 \pm 0.60$ & $2.59 \pm 0.88$ & $2.01 \pm 0.34$ & $3.11 \pm 1.08$ & ns \\
\hline SCFA & $0.82 \pm 0.68^{\mathrm{a}}$ & $1.06 \pm 0.38^{\mathrm{a}}$ & $0.41 \pm 0.02^{b}$ & $1.68 \pm 1.14^{\mathrm{a}}$ & 0.03 \\
\hline MCFA & $16.94 \pm 4.00$ & $17.65 \pm 3.15$ & $14.50 \pm 0.73$ & $21.27 \pm 6.97$ & $\mathrm{~ns}$ \\
\hline LCFA & $82.26 \pm 4.40$ & $81.28 \pm 3.11$ & $85.09 \pm 0.75$ & $77.05 \pm 7.94$ & $\mathrm{~ns}$ \\
\hline
\end{tabular}

Means in a row with common superscripts do not differ.

$$
\mathrm{IA}=\frac{(\mathrm{C} 12: 0+4 \times \mathrm{C} 14: 0+\mathrm{C} 16: 0)}{(\mathrm{C} 10: 1+\mathrm{C} 14: 1+\mathrm{C} 16: 1+\mathrm{C} 17: 1+\mathrm{C} 18: 1+\mathrm{C} 18: 2+\mathrm{C} 18: 3)} .
$$

SCFA $=\Sigma$ C4:0 to C8:0.

MCFA $=\Sigma$ C10:0 to C15:0.

LCFA $=\Sigma$ C16:0 to C20:1.

was lower in dromedary milk samples than in mixed samples, contrary to iso-heptadecanoic (C17:0iso) and oleic (C18:1) acids (Tab. IV).
No significant variation was observed when the total of short-chain fatty acids / medium-chain fatty acids / long-chain fatty acids was considered (Tab. IV). 
Table III. Fatty acid composition of camel milk fat harvested in 4 different seasons (IA: index of atherogenicity; SCFA: short-chain fatty acids; MCFA: medium-chain fatty acids; LCFA: long-chain fatty acids).

\begin{tabular}{|c|c|c|c|c|c|}
\hline Acids & Winter $(n=3)$ & Spring $(n=8)$ & Summer $(\mathrm{n}=8)$ & Autumn $(\mathrm{n}=3)$ & $P$ value \\
\hline C4:0 & $0.28 \pm 0.24^{\mathrm{a}}$ & $0.58 \pm 0.64^{b}$ & $0.26 \pm 0.09^{\mathrm{a}}$ & $0.25 \pm 0.09^{\mathrm{a}}$ & 0.04 \\
\hline C6:0 & $0.14 \pm 0.07$ & $0.50 \pm 0.32$ & $0.40 \pm 0.29$ & $0.24 \pm 0.12$ & ns \\
\hline C8:0 & $0.10 \pm 0.07^{\mathrm{b}}$ & $0.60 \pm 0.34^{\mathrm{a}}$ & $0.40 \pm 0.31^{\mathrm{a}}$ & $0.21 \pm 0.07^{\mathrm{a}}$ & $<0.001$ \\
\hline C10:0 & $0.11 \pm 0.07^{\mathrm{a}}$ & $0.61 \pm 0.56^{\mathrm{b}}$ & $0.26 \pm 0.18^{\mathrm{a}}$ & $0.12 \pm 0.04^{\mathrm{a}}$ & 0.001 \\
\hline C10:1 & $0.38 \pm 0.29^{\mathrm{a}}$ & $1.54 \pm 1.75^{\mathrm{b}}$ & $0.54 \pm 0.22^{\mathrm{a}}$ & $0.33 \pm 0.11^{\mathrm{a}}$ & 0.01 \\
\hline C12:0 & $0.72 \pm 0.30^{\mathrm{a}}$ & $1.24 \pm 0.61^{\mathrm{b}}$ & $0.97 \pm 0.37^{\mathrm{a}}$ & $0.84 \pm 0.18^{\mathrm{a}}$ & 0.03 \\
\hline C13:0 & $0.03 \pm 0.02$ & $0.16 \pm 0.35$ & $0.02 \pm 0.03$ & $0.03 \pm 0.04$ & $\mathrm{~ns}$ \\
\hline C14:0iso & $0.16 \pm 0.03$ & $0.18 \pm 0.20$ & $0.14 \pm 0.11$ & $0.18 \pm 0.11$ & $\mathrm{~ns}$ \\
\hline C14:0 & $10.27 \pm 2.28$ & $14.24 \pm 4.63$ & $12.49 \pm 3.97$ & $12.57 \pm 4.87$ & ns \\
\hline C14:1 & $0.47 \pm 0.16$ & $0.86 \pm 0.45$ & $0.68 \pm 0.12$ & $0.77 \pm 0.56$ & ns \\
\hline C14:0dm & $0.46 \pm 0.14$ & $0.36 \pm 0.19$ & $0.40 \pm 0.40$ & $0.34 \pm 0.17$ & ns \\
\hline C15:0iso & $0.76 \pm 0.14^{\mathrm{a}}$ & $0.67 \pm 0.19^{\mathrm{a}}$ & $0.88 \pm 0.21^{\mathrm{b}}$ & $0.92 \pm 0.15^{\mathrm{b}}$ & 0.02 \\
\hline C15:0 & $1.30 \pm 0.22$ & $1.18 \pm 0.31$ & $1.28 \pm 0.27$ & $1.65 \pm 0.56$ & ns \\
\hline C16:0iso & $0.28 \pm 0.15$ & $0.29 \pm 0.18$ & $0.26 \pm 0.22$ & $0.27 \pm 0.09$ & ns \\
\hline C16:0 & $26.20 \pm 0.68^{b}$ & $30.69 \pm 3.14^{\mathrm{a}}$ & $33.55 \pm 3.72^{\mathrm{a}}$ & $32.36 \pm 6.23^{\mathrm{a}}$ & 0.04 \\
\hline C16:1 & $5.69 \pm 0.36$ & $6.63 \pm 1.61$ & $7.26 \pm 0.99$ & $8.17 \pm 2.64$ & ns \\
\hline C16:0dm & $0.45 \pm 0.21$ & $0.37 \pm 0.17$ & $0.44 \pm 0.33$ & $0.33 \pm 0.18$ & ns \\
\hline C17:0iso & $0.80 \pm 0.20$ & $0.51 \pm 0.21$ & $0.63 \pm 0.39$ & $0.82 \pm 0.30$ & ns \\
\hline C17:0 & $0.68 \pm 0.05^{\mathrm{a}}$ & $0.62 \pm 0.21^{\mathrm{a}}$ & $0.66 \pm 0.24^{\mathrm{a}}$ & $0.91 \pm 0.25^{\mathrm{b}}$ & 0.003 \\
\hline C17:1 & $0.32 \pm 0.09^{\mathrm{a}}$ & $0.31 \pm 0.16^{\mathrm{a}}$ & $0.32 \pm 0.16^{\mathrm{a}}$ & $0.56 \pm 0.17^{b}$ & 0.004 \\
\hline C18:0 & $19.02 \pm 2.27$ & $16.03 \pm 6.26$ & $16.17 \pm 3.13$ & $14.87 \pm 5.66$ & ns \\
\hline C18:1 & $29.33 \pm 1.38$ & $19.72 \pm 4.73$ & $20.16 \pm 4.69$ & $21.28 \pm 6.04$ & ns \\
\hline C18:2 & $1.74 \pm 0.70$ & $1.42 \pm 0.50$ & $1.23 \pm 0.38$ & $1.27 \pm 0.55$ & ns \\
\hline C18:3 & $0.09 \pm 0.09$ & $0.70 \pm 0.48$ & $0.62 \pm 0.66$ & $0.75 \pm 0.68$ & ns \\
\hline C20:0 & $0.15 \pm 0.14^{\mathrm{b}}$ & $0.00^{\mathrm{a}}$ & $0.01 \pm 0.02^{\mathrm{a}}$ & $0.00^{\mathrm{a}}$ & 0.001 \\
\hline C20:1 & $0.04 \pm 0.05$ & $0.02 \pm 0.05$ & 0.00 & 0.00 & ns \\
\hline IA & $2.56 \pm 0.68$ & $2.65 \pm 1.07$ & $2.85 \pm 0.96$ & $2.61 \pm 0.16$ & ns \\
\hline SCFA & $0.52 \pm 0.29$ & $1.67 \pm 1.16$ & $1.06 \pm 0.62$ & $0.70 \pm 0.11$ & ns \\
\hline MCFA & $14.66 \pm 2.76$ & $21.03 \pm 6.21$ & $17.64 \pm 4.46$ & $17.76 \pm 4.06$ & ns \\
\hline LCFA & $84.81 \pm 3.06$ & $77.31 \pm 7.17$ & $81.29 \pm 4.89$ & $81.53 \pm 4.63$ & ns \\
\hline
\end{tabular}

Means in a row with common superscripts do not differ.

The index of atherogenicity varied from 1.53 to 4.42 with an average of 2.71 $( \pm 0.95)$, but no significant variation was observed between regions (Tab. II), seasons (Tab. III) or species (Tab. IV).

\subsection{Multivariate analysis}

The multiple correspondence factorial analyses allowed the identification of a main factorial plan representing $35 \%$ of the total variance. To facilitate the inter- pretation of the factorial plan, only the main fatty acids (C14:0, C16:0, C18:0 and C18:1) were represented (Figs. 1 and 2).

By regarding the main fatty acids, the first factor (F1) corresponded to a gradient of medium-chain fatty acids (Fig. 1) from the right side of the plan (modalities "low") to the left side (modalities "high") as shown in Figure 1a (C14:0 and C16:0). This gradient was reversed in the longchain fatty acids (C18:0 and C18:1) as the modalities "high" are on the right side of 
Table IV. Fatty acid composition of camel milk fat by species of Kazakhstan (IA: index of atherogenicity; SCFA: short-chain fatty acids; MCFA: medium-chain fatty acids; LCFA: long-chain fatty acids).

\begin{tabular}{|c|c|c|c|c|c|}
\hline$\overline{\text { Acids }}$ & Bactrian $(\mathrm{n}=7)$ & Dromedary $(\mathrm{n}=10)$ & Hybrids $(\mathrm{n}=3)$ & $\operatorname{Mix}(\mathrm{n}=2)$ & $P$ value \\
\hline C4:0 & $0.54 \pm 0.63$ & $0.34 \pm 0.29$ & $0.20 \pm 0.20$ & $0.25 \pm 0.09$ & ns \\
\hline C6:0 & $0.46 \pm 0.39$ & $0.29 \pm 0.16$ & $0.35 \pm 0.34$ & $0.60 \pm 0.30$ & ns \\
\hline C8:0 & $0.53 \pm 0.41^{\mathrm{b}}$ & $0.27 \pm 0.19^{\mathrm{a}}$ & $0.41 \pm 0.44^{\mathrm{a}}$ & $0.65 \pm 0.17^{\mathrm{b}}$ & 0.02 \\
\hline C10:0 & $0.46 \pm 0.51$ & $0.27 \pm 0.39$ & $0.30 \pm 0.34$ & $0.38 \pm 0.01$ & ns \\
\hline C10:1 & $1.15 \pm 1.44$ & $0.81 \pm 1.22$ & $0.54 \pm 0.60$ & $0.51 \pm 0.04$ & ns \\
\hline C12:0 & $1.24 \pm 0.58^{b}$ & $0.80 \pm 0.20^{\mathrm{a}}$ & $1.00 \pm 0.69^{\mathrm{a}}$ & $1.33 \pm 0.35^{\mathrm{b}}$ & 0.03 \\
\hline C13:0 & $0.17 \pm 0.38$ & $0.03 \pm 0.06$ & $0.01 \pm 0.01$ & $0.03 \pm 0.04$ & ns \\
\hline C14:0iso & $0.20 \pm 0.19$ & $0.17 \pm 0.17$ & $0.06 \pm 0.02$ & $0.09 \pm 0.13$ & $\mathrm{~ns}$ \\
\hline C14:0 & $15.43 \pm 4.09^{\mathrm{a}}$ & $10.10 \pm 1.32^{\mathrm{b}}$ & $12.95 \pm 5.71^{\mathrm{a}}$ & $17.19 \pm 3.68^{\mathrm{a}}$ & 0.001 \\
\hline C14:1 & $0.80 \pm 0.42^{\mathrm{a}}$ & $0.57 \pm 0.15^{\mathrm{b}}$ & $0.86 \pm 0.52^{\mathrm{a}}$ & $1.11 \pm 0.40^{\mathrm{a}}$ & 0.04 \\
\hline C14:0dm & $0.32 \pm 0.17$ & $0.50 \pm 0.33$ & $0.28 \pm 0.21$ & $0.20 \pm 0.13$ & ns \\
\hline C15:0iso & $0.77 \pm 0.21$ & $0.88 \pm 0.20$ & $0.60 \pm 0.13$ & $0.72 \pm 0.00$ & ns \\
\hline C15:0 & $1.41 \pm 0.50$ & $1.24 \pm 0.18$ & $1.07 \pm 0.16$ & $1.54 \pm 0.38$ & ns \\
\hline C16:0iso & $0.22 \pm 0.14$ & $0.34 \pm 0.21$ & $0.21 \pm 0.05$ & $0.24 \pm 0.19$ & ns \\
\hline C16:0 & $32.05 \pm 3.83$ & $29.74 \pm 4.62$ & $32.56 \pm 2.66$ & $35.07 \pm 3.64$ & ns \\
\hline C16:1 & $7.01 \pm 2.01$ & $6.60 \pm 1.31$ & $6.74 \pm 1.01$ & $8.65 \pm 0.73$ & ns \\
\hline C16:0dm & $0.38 \pm 0.20$ & $0.44 \pm 0.30$ & $0.34 \pm 0.21$ & $0.34 \pm 0.01$ & ns \\
\hline C17:0iso & $0.55 \pm 0.27^{\mathrm{a}}$ & $0.82 \pm 0.24^{\mathrm{b}}$ & $0.49 \pm 0.21^{\mathrm{a}}$ & $0.23 \pm 0.32^{\mathrm{a}}$ & 0.003 \\
\hline C17:0 & $0.65 \pm 0.32$ & $0.76 \pm 0.17$ & $0.61 \pm 0.12$ & $0.58 \pm 0.15$ & ns \\
\hline C17:1 & $0.33 \pm 0.25$ & $0.38 \pm 0.13$ & $0.33 \pm 0.17$ & $0.30 \pm 0.01$ & ns \\
\hline C18:0 & $14.75 \pm 5.55$ & $17.82 \pm 3.70$ & $17.69 \pm 5.35$ & $12.33 \pm 1.92$ & ns \\
\hline C18:1 & $18.78 \pm 4.68^{\mathrm{a}}$ & $24.66 \pm 4.63^{b}$ & $20.64 \pm 5.38^{b}$ & $15.45 \pm 1.49^{\mathrm{a}}$ & 0.002 \\
\hline C18:2 & $1.19 \pm 0.45$ & $1.61 \pm 0.51$ & $1.10 \pm 0.41$ & $1.26 \pm 0.27$ & ns \\
\hline C18:3 & $0.60 \pm 0.41$ & $0.51 \pm 0.71$ & $0.67 \pm 0.36$ & $0.88 \pm 0.72$ & ns \\
\hline C20:0 & $0.01 \pm 0.02$ & $0.05 \pm 0.09$ & 0.00 & 0.00 & ns \\
\hline C20:1 & $0.00^{\mathrm{a}}$ & $0.01 \pm 0.03^{\mathrm{a}}$ & $0.00^{\mathrm{a}}$ & $0.07 \pm 0.10^{\mathrm{b}}$ & 0.05 \\
\hline IA & $2.30 \pm 0.71$ & $2.75 \pm 0.91$ & $2.85 \pm 1.12$ & $3.72 \pm 0.22$ & ns \\
\hline SCFA & $1.52 \pm 1.25$ & $0.89 \pm 0.55$ & $0.95 \pm 0.79$ & $1.50 \pm 0.39$ & ns \\
\hline MCFA & $21.95 \pm 5.70$ & $15.38 \pm 2.42$ & $17.67 \pm 6.32$ & $23.09 \pm 3.60$ & ns \\
\hline LCFA & $76.51 \pm 6.76$ & $83.73 \pm 2.80$ & $81.37 \pm 7.10$ & $75.40 \pm 3.20$ & $\mathrm{~ns}$ \\
\hline
\end{tabular}

Means in a row with common superscripts do not differ.

the main factor and modalities "low" on the left side (Fig. 1b).

The ascending hierarchical classification applied to the transformed data table allowed 4 classes to be well distributed all along the first factor (Fig. 2).

The description of these four classes (Tab. V) confirmed the observed gradients. From the left side to the right side of the main factor, the milk samples were richer in long-chain fatty acids: for example, the percentage of C18:0 was 12.3 in class $1,13.05$ in class $2,18.3$ in class 4 and 20.9 in class 3 . Conversely, the mediumchain fatty acids were in higher proportion in class 1: for example, the percentage of C14 was 17.4 in class $1,14.9$ in class 2, 10.1 in class 4 and 9.5 in class 3 .

So, the class 1 included milk samples rich in short- and medium-chain fatty acids but poor in long-chain fatty acids. Those samples were from Bactrian camels from the Shymkent region and collected in spring and summer. The class 2 (richer in 


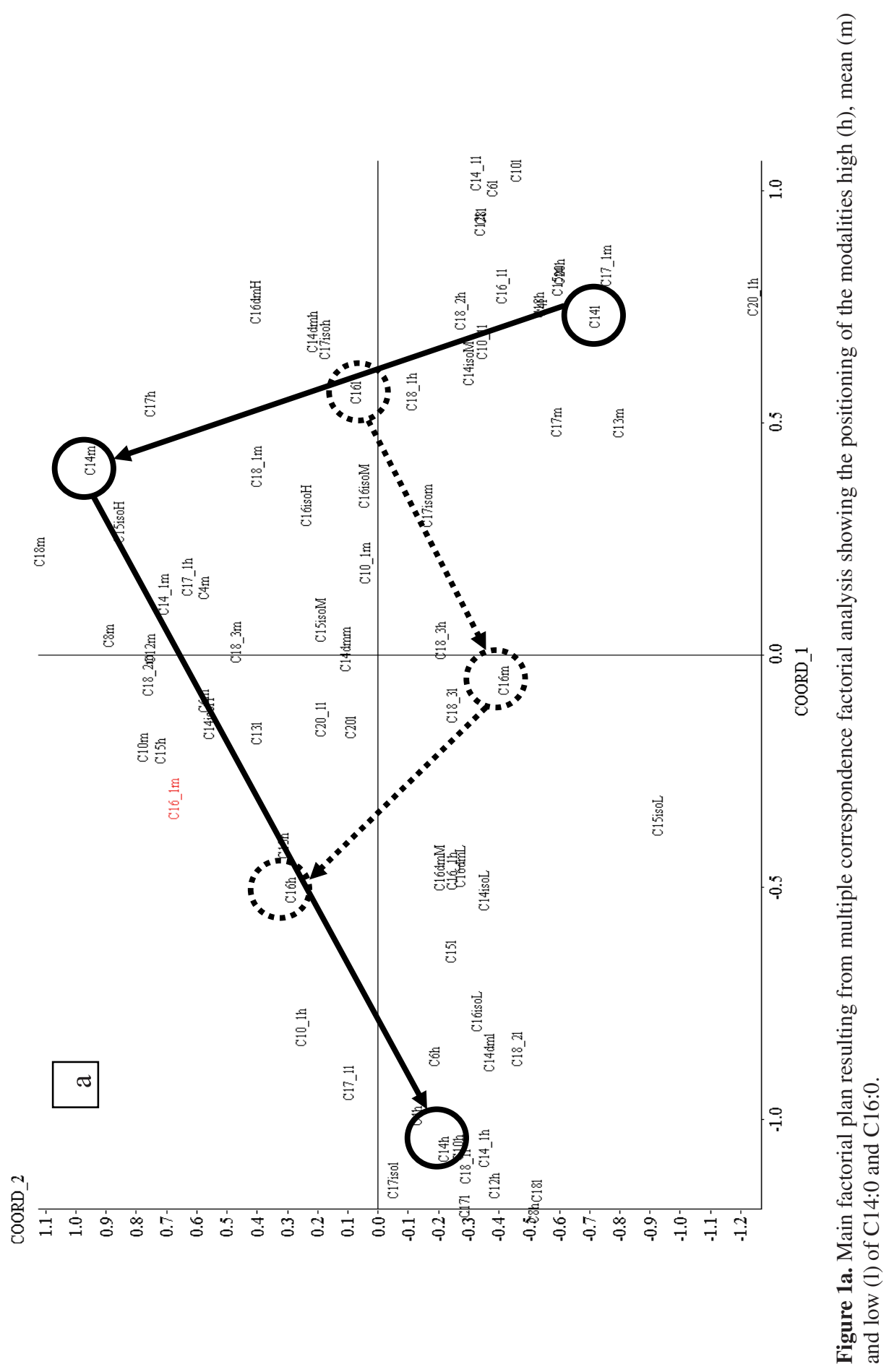




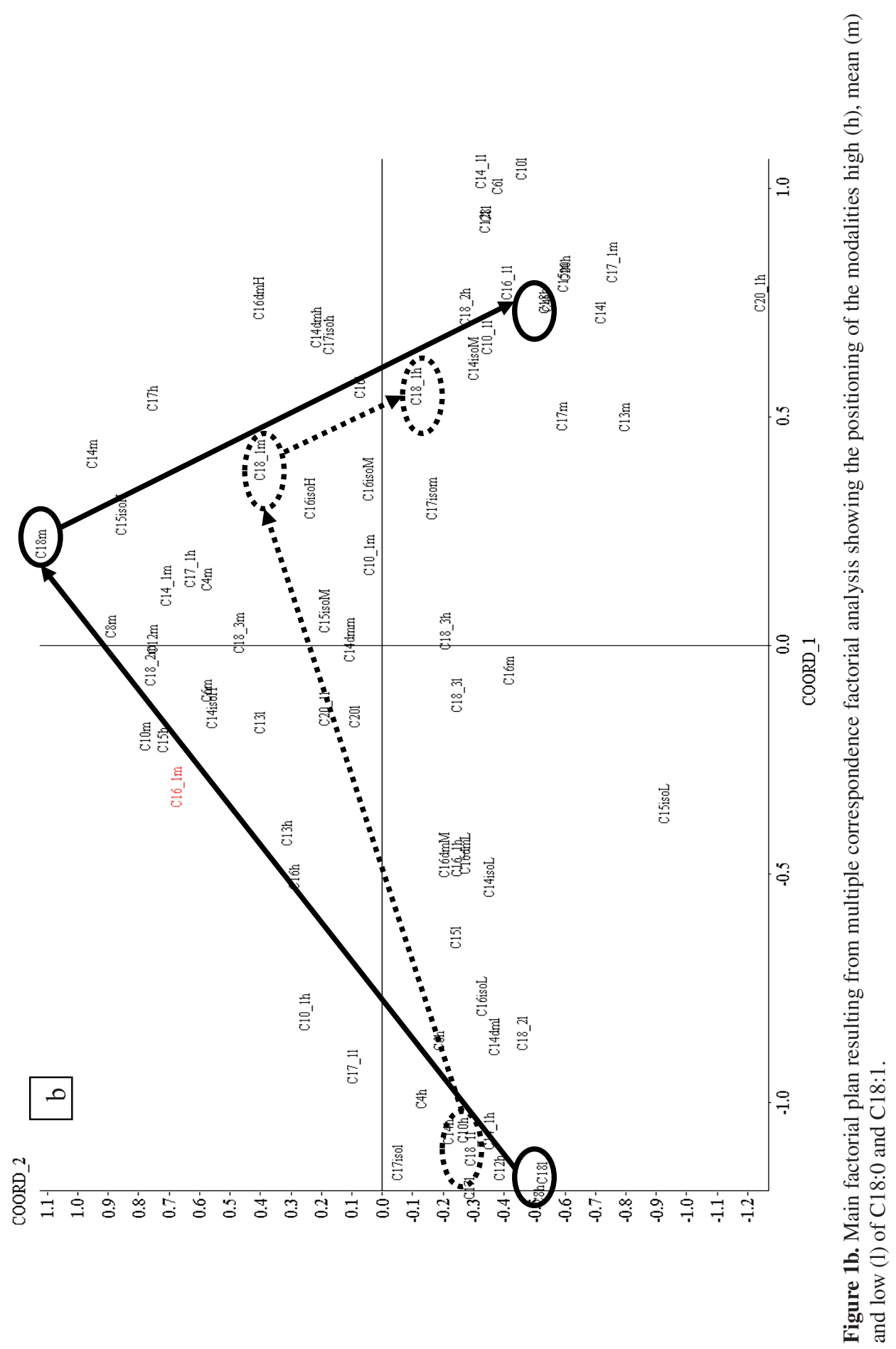




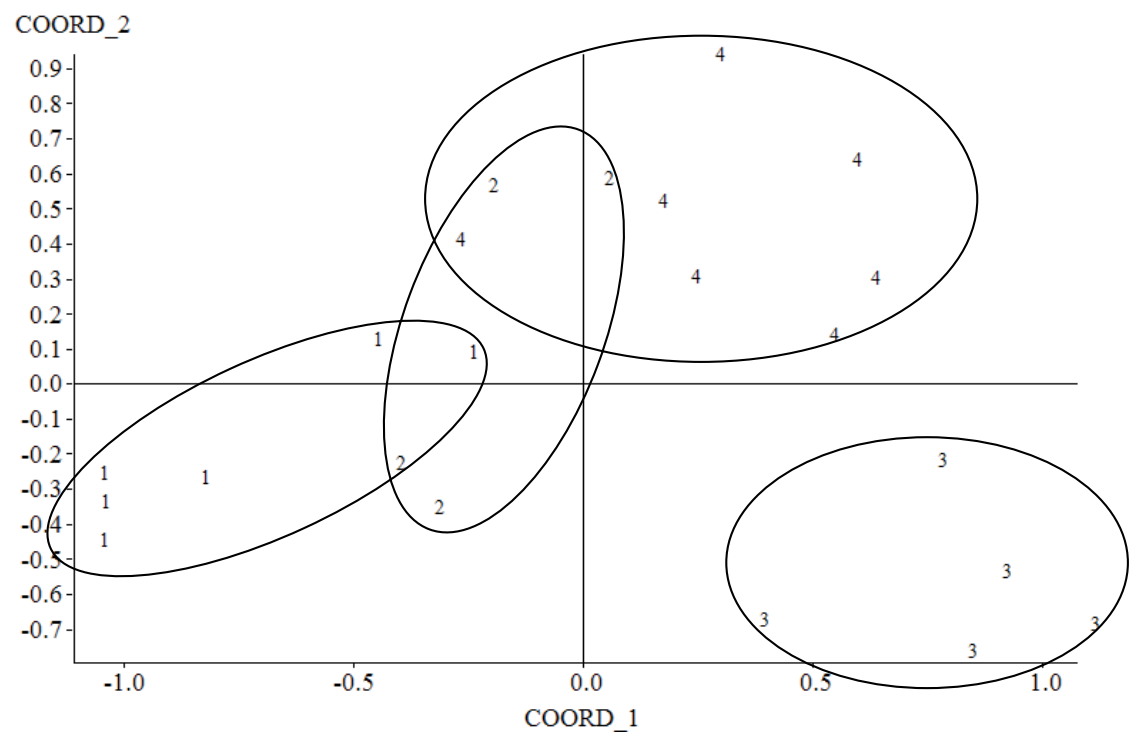

Figure 2. Representation of the four classes resulting from classification analysis on the main factorial plan showing the distribution of the four groups of samples all along the main factor.

Table V. Percentage of fatty acids (short-chain $\mathrm{C} 4: 0$ to $\mathrm{C} 8: 0$, medium-chain $\mathrm{C} 10: 0$ to $\mathrm{C} 16: 0$, and long-chain $\mathrm{C} 17: 0$ to $\mathrm{C} 20: 0)$ in the different classes issued from the classification analysis.

\begin{tabular}{crrrr}
\hline \multirow{2}{*}{ Fatty acid groups } & \multicolumn{4}{c}{ Class number } \\
\cline { 2 - 5 } & \multicolumn{1}{c}{$\mathbf{1}$} & \multicolumn{1}{c}{$\mathbf{4}$} & \multicolumn{1}{c}{$\mathbf{3}$} \\
\hline C4:0 - C8:0 & 2.15 & 1.28 & 0.81 & 0.37 \\
C10:0 - C16:0 & 66.82 & 60.36 & 53.65 & 49.19 \\
C17:0 - C20:0 & 31.03 & 38.49 & 45.52 & 50.48 \\
\hline
\end{tabular}

C10:1, C14iso and C15:0) was characteristic of dromedaries living in the Atyrau region in spring. The class 4 (richer in C15iso, $\mathrm{C} 17: 0$ and $\mathrm{C} 17: 1$ ) was linked to the dromedaries from the Aralsk and Almaty regions in winter milk only. Finally, class 3, the richest milk in long-chain fatty acids, came from dromedaries and hybrids from all over Kazakhstan (except the Aralsk region), especially in summer milk.

\subsection{Cholesterol content}

In the camel's milk samples from Kazakhstan, the cholesterol concentration was $37.15( \pm 7.73) \mathrm{mg} \cdot 100 \mathrm{~g}^{-1}$ of milk, with min and max values of 25.61 to $50.42 \mathrm{mg} \cdot 100 \mathrm{~g}^{-1}$, respectively.

\section{DISCUSSION}

Three variation factors were taken into account (region, season and species) despite the role of feeding and physiological stage on the FA composition [6, 20,21]. In Kazakhstan, the calving season was concentrated within two months (FebruaryMarch). So the season factor reflected the physiological status of the camels. Elsewhere, all the animals were in extensive systems with only natural pasture (steppe) as food, with no supplement except hay from natural grassland during winter. So, the quality of the food was mainly linked to the season and region factors. The most contrasted seasons for the short-chain FA composition (C8:0 and C10:0) were the winter (forages with low nutritive value and females at the end of lactation) and spring (green forages and animals at the 
beginning of their lactation). In autumn, when the forages had a low nutritive value and the animals were at the medium stage of lactation, the milk appeared richer in long-chain FA (C17:0 and C17:1). The observed FA compositions in the present study did not have the same trend as in cow's milk [26], where the short-chain FA were in higher proportion in winter milk and long-chain FA in summer milk. The regions also reflected the nutritional status of the animals. For example, the pastures of the Shymkent region (in the south of the country), with Haloxylon sp., Tamarix sp. and Artemisia sp. dominating the pastures, had milk samples richer in shortchain FA, even though this content remained very different from that of cow's milk $(8.99 \%)$ [23].

On the contrary, in the Aralsk and Atyrau regions located in the north of the country, where the genera Stipa, Fetuca and Avena were dominant in the pasture, the milk appeared rather richer in some long-chain FA. Generally, cow's milk is richer in long-chain FA, with a diet including more natural grassland compared with a diet with silage or mixed ration [20,24], but no references were available for the natural pasture in Central Asia. Few differences occurred between the species but dromedaries had milk richer in some longchain FA. The species effect could be linked to the region effect: indeed, Bactrian camels were usually more common in the Atyrau and Aralsk areas, and dromedaries around Shymkent and Almaty. However, in our sampling design, the balance between species within the region was respected (Tab. I).

The total lipid content in camel's milk from Kazakhstan appeared higher (average of $6.40 \%$ ) than in the literature data [10]. The observed values in the present samples confirmed our previous observations on 31 camel samples analyzed in Kazakhstan [22]. In another study of our team [17], 176 Kazakh camel's milk samples showed high content of lipid matter. The values observed for Bactrian camels $(6.67 \pm 2.93 \%)$, dromedaries $(5.94 \pm 2.26 \%)$ and hybrids (6.09 \pm $1.81 \%$ ) were higher than those reported by Farah [10].

Fatty acids were determined after methylation by gas chromatography, as in most of the literature references [11]. In our case, the fatty acid identification was confirmed by mass spectrometry for each milk sample.

The fatty acid composition of camel milk fat from Kazakhstan was comparable with results in the literature, in particular the content of unsaturated fatty acids, which was higher than in cow's milk, and the content of short-chain fatty acids, which was lower than in cow's milk [1, $3,11,16]$. The camel's milk was poor in short-chain fatty acids $(\mathrm{C} 4: 0=0.37 \%)$ when compared with cow's milk, which contains more than $3.0 \%$ of butyric acid [ 2 , 23, 25]. This confers upon camel's milk some interesting nutritional properties; in particular, if we refer to some papers classifying short-chain fatty acids as promoters of atherosclerosis. The sum of shortchain fatty acids $\mathrm{C} 4: 0$ to $\mathrm{C} 8: 0$ was only $1.15 \%$ in camel's milk, and $8.99 \%$ in the milk of cows fed with a nutritionally balanced diet [23]. The medium-chain fatty acids (C4 to C14) were $16.38 \%$ in camel's milk and $21.44 \%$ in cow's milk. The longchain fatty acids $\mathrm{C} 15$ to $\mathrm{C} 20: 1$ were much higher $(82.43 \%)$ in camel's milk than in cow's milk $(66.1 \%)$ [23]. The ratio saturated/unsaturated fatty acids was similar in the two species: 67.7 for camel's milk and 69.9 for cow's milk, but in favor of camel's milk in terms of unsaturated fatty acid content. Content of $\mathrm{C} 18: 3$ was 10 times more in camel's milk (0.6) than in cow's milk (0.07).

In most of the literature data $[1,4$, $12,13,16,21,29]$, the fatty acid composition was given without taking into account the variability due to environmental 
or physiological conditions. Yet, a high variability was observed between the animals, even if the variation factors such as genetic (dromedary, Bactrian and hybrids), season or region seem to have a low effect in the context of the present study, especially because of the low number of samples for each variation factor. Especially, types of milk were identified according to their fatty acid profiles. It was remarkable that there was a clear opposition between milk rich in long-chain fatty acids and milk rich in short- and medium-chain fatty acids.

Milk fatty acid composition is of particular importance for human consumers, both from nutritional and health points of view. Milk products furnish 15 to $25 \%$ of the fat matter consumed by humans, and 25 to $35 \%$ of the saturated fats [5].

The IA is highly associated with the onset of coronary heart diseases that are principally due to obstruction of coronary vessels by atherosclerosis [28]. This index was proposed to take into account better the effects of different foods and diets on human health. High values of such an index reflect the risk of cardiovascular disease resulting from lipid intake. For milk, butter and cheese, the IA values are higher than 2.0, while for meat IA values range from 0.7 to 1.0 [28]. The index of atherogenicity was between 3.3 and 3.5 in cow's milk with standard feeding [5]. In the case of camel's milk, this index was generally lower: 2.7 on average in our samples. So, on average, camel's milk appeared healthier for milk consumers and gave an advantage to camel's milk for nutritional aspects.

It is of particular importance in Kazakhstan where the milk annual consumption per inhabitant is high (more than $250 \mathrm{~kg} /$ habitant/year).

The ratio unsaturated fatty acids/ saturated fatty acids is a good indicator of the nutritional quality of milk. This ratio was 0.45 for Bactrian and 0.43 for dromedary milk in our study, compared with 0.30 for cow's and 0.32 for goat's milk [4]. A higher content of mediumchain fatty acids is usually considered as beneficial for human health as they are more easily absorbed and metabolized than long-chain fatty acids.

Cholesterol content in camel's milk appeared higher than in cow's milk, $\left(12-17 \mathrm{mg} \cdot 100 \mathrm{~g}^{-1}\right)$ [25] or ovine milk (28.8 mg. $\left.100 \mathrm{~g}^{-1}\right)$ [15].

In their comparative study, Gorban and Izzeldin [14] confirmed that camel's milk had a higher content of total cholesterol (31.3 mg.100 $\mathrm{g}^{-1}$ ) compared with cow's milk $\left(25.6 \mathrm{mg} \cdot 100 \mathrm{~g}^{-1}\right)$. The free cholesterol content in milk from lactating camels was $21.3 \mathrm{mg} \cdot 100 \mathrm{~g}^{-1}$ vs. 7.2 in lactating cow's milk. So, the nutritional advantage of camel's milk due to fatty acid composition could be reduced by the higher content of cholesterol. This higher value could be due to the total fat content of camel's milk (6.4\% in average) which is nearly twice that in cow's milk (3.4\% on average).

\section{CONCLUSION}

The fatty acid composition of camel's milk from Kazakhstan confirmed the nutritional and health interest of this product in spite of a higher content of cholesterol compared with cow's milk [19]. Camel's milk seems to be very different from other mammalian milks consumed by humans in terms of unsaturated fatty acid composition and in its low content of short-chain fatty acids. In spite of the large number of samples studied, a more significant number of milk samples would be necessary to understand better the variability in lipid composition. Indeed, it was possible to identify some types of milk according to their fatty acid profiles, but the high number of variable factors (species, season and region) in our study compared with the limited number of samples did not allow the confirmation of a statistical link with any factor. 


\section{REFERENCES}

[1] Abu-Lehia I.H., Physical and chemical characteristics of camel milk fat and its fractions, Food Chem. 34 (1989) 267-271.

[2] Agabriel C., Ferlay A., Journal C., Sibra C., Teissier D., Grolier P., Bonnefoy J.C., Rock E., Chilliard Y., Martin B., Composés d'intérêt nutritionnel de laits de grand mélange : teneurs en acides gras et vitamines selon l'altitude et la saison, in: Proc. 11th Symposium Rencontres Recherches Ruminants, Paris, France, 8-9 December, 2004, pp. 51-54.

[3] Attia H., Kherouatou N., Fakhfakh N., Khorchani T., Trigui N., Dromedary milk fat: biochemical, microscopic and rheological characterics, J. Food Lipids 7 (2000) 95112.

[4] Cardak A.D., Yetismeyen A., Brückner H., Quantitative comparison of free fatty acids in camel, goat and cow milk, Milchwissenschaft 58 (2003) 127-130.

[5] Chilliard Y., Ferlay A., Doreau M., Contrôle de la qualité nutritionnelle des matières grasses du lait par l'alimentation des vaches laitières : acides gras trans, polyinsaturés, acide linoléique conjugué, INRA Prod. Anim. 14 (2001) 323-335.

[6] Chilliard Y., Ferlay A., Mansbridge R.M., Doreau M., Ruminant milk fat plasticity: nutritional control of saturated, polyunsaturated, trans and conjugated fatty acids, Ann. Zootech. 49 (2000) 181-205.

[7] Collomb M., Bühler T., Analyse de la composition en acides gras de la graisse de lait, Mitt. Geb. Lebebsm. Unters. Hyg. 91 (2000) 306-332.

[8] Contarini G., Povolo M., Bonfitto E., Berardi S., Quantitative analysis of sterols in dairy products: experiences and remarks, Int. Dairy J. 12 (2002) 573-578.

[9] Djangabilov A.K., Bekishev A.C., Mamirova T.N., Medicinal properties of camel milk and shubat, in: 2nd International Proc. Camelid Conference, "Agroeconomics of camelid farming", Agromercur publ., 8-12 September, Almaty, Kazakhstan, 2000.

[10] Farah Z., Composition and characteristics of camel milk. Review article, J. Dairy Res. 60 (1993) 603-626.

[11] Farah Z., Camel milk, properties and products, Swiss Centre for the Development and Cooperation (SKAT publication), St-Gallen, Switzerland, 1996.

[12] Farah Z., Streiff T., Bachmann M.R., Manufacture and characterisation of camel milk butter, Milchwissenschaft 44 (1989) 412-414.
[13] Gnan S.O., Sherida A.M., Composition of Lybian camel's milk, Aust. J. Dairy Technol. 41 (1986) 33-35.

[14] Gorban A.M.S., Izzeldin O.M., Study on cholesteryl ester fatty acids in camel and cow milk lipid, Int. J. Food Sci. Technol. 34 (1999) 229-234.

[15] Goudjil H., Torrado S., Fontecha J., Martinez-Castro I., Fraga J., Juarez M., Composition of cholesterol and its precursor in ovine milk, Lait 83 (2003) 153-160.

[16] Karray N., Lopez C., Ollivon M., Attia H., La matière grasse du lait de dromadaire : composition, microstructure et polymorphisme. Une revue, O1. Corps Gras Lipides 12 (2005) 439-446.

[17] Konuspayeva G., Variabilité physicochimique et biochimique du lait des grands camélidés (Camelus bactrianus, Camelus dromedarius et hybrides) au Kazakhstan, Ph.D. thesis, Université Montpellier II, France, 2007, 255 p.

[18] Konuspayeva G., Faye B., A better knowledge of milk quality parameters: A preliminary step for improving the camel milk market opportunity in a transition economy - The case of Kazakhstan, in: International Conference on "Saving the camel and peoples' livelihood", Sadri, India, 23-25 November 2004, pp. 28-36.

[19] Konuspayeva G., Loiseau G., Faye B., La plus-value "santé" du lait de chamelle cru et fermenté : l'expérience du Kazakhstan, in: Proc. 11th Symposium Rencontres Recherches Ruminants, Paris, France, 8-9 December 2004, pp. 47-50.

[20] Martin B., Ferlay A., Pradel P., Rock E., Grolier P., Dupont D., Gruffat D., Besle J.M., Ballot N., Chilliard Y., Coulon J.B., Variabilité de la teneur des laits en constituants d'intérêt nutritionnel selon la nature des fourrages consommés par les vaches laitières, in: Proc. 9th Symposium Rencontres Recherches Ruminants, Paris, France, 2002, pp. 347-350.

[21] Mohamed M.A., Camel milk: chemical composition, characterisation of casein and preliminary trial of cheese-making, Ph.D. Diss. Sveriges Lantbrukunibersitet, Uppsala, Sweden, 1990.

[22] Narmuratova M., Konuspayeva G., Loiseau G., Serikbaeva A., Barouh N., Montet D., Faye B., Fatty acids composition of dromedary Bactrian camel milk in Kazakhstan, J. Camel Pract. Res. 13 (2006) 45-50.

[23] Palmquist D.L., Baulieu A.D., Barbano D.M., Feed and animal factors influencing 
milk fat composition, J. Dairy Sci. 76 (1993) 1753-1771.

[24] Schroeder G.F., Delahoy J.E., Vidaurreta I., Bargo F., Gagliostro G.A., Muller L.D., Milk fatty acid composition of cows fed a total mixed ration or pasture plus concentrates replacing corn with fat, J. Dairy Sci. 86 (2003) 3237-3248.

[25] Sieber R., Oxidised cholesterol in milk and dairy products, Int. Dairy J. 15 (2005) 191206.

[26] Sollberger H., Schaeren W., Collomb M., Badertscher R., Bütikofer U., Sieber R., Beitrag zur kenntnis der Zusammensetzung von ziegenmilch schweizerisher herkunft,
Agroscope Liebefeld-Posieux (ALP) Sci. 473 (2004) 3-15.

[27] Ulbricht T.L.V., Southgate D.A.T., Coronary heart disease: seven dietary factors, Lancet 338 (1991) 985-992.

[28] Wahle K.W., Heys S.D., Cell signal mechanisms, conjugated linoleic acids (CLAs) and anti-tumorigenesis, Prostagland. Leuk. Essent Fat. Acids 67 (2002) 183-186.

[29] Zhang H., Yao J., Zhao D., Liu H., Guo M., Changes in chemical composition of Alxa Bactrian camel milk during lactation, J. Dairy Sci. 88 (2005) 3402-3410. 